Lošák T., Ševčík M., Plchová R., von Bennewitz E., Hlušek J., Elbl J., Buňka F., Polášek Z., Antonkiewicz J., Varga L., Vollmann J. 2018.

Nitrogen and sulphur fertilisation affecting soybean seed spermidine content. J. Elem., 23(2): 581-588. DOI: 10.5601/jelem.2017.22.3.1516

\title{
NITROGEN AND SULPHUR FERTILISATION AFFECTING SOYBEAN SEED SPERMIDINE CONTENT*
}

\author{
Tomáš Lošák ${ }^{1}$, Michal Ševčík ${ }^{1}$, Radka Plchová ${ }^{1}$ \\ Eduardo von Bennewitz ${ }^{1}$, Jaroslav Hlušek ${ }^{1}$, Jakub Elbl ${ }^{2}$, \\ František Buňka ${ }^{3}$, Zdeněk Polášek ${ }^{3}$, Jacek Antonkiewicz ${ }^{4}$, \\ Ladislav Varga ${ }^{5}$, Johann Vollmann ${ }^{6}$
}

\author{
${ }^{1}$ Department of Environmentalistics and Natural Resources \\ ${ }^{2}$ Department of Geology and Pedology \\ Mendel University in Brno, Czech Republic \\ ${ }^{3}$ Department of Food Technology \\ Tomas Bata University in Zlín, Czech Republic \\ ${ }^{4}$ Department of Agricultural and Environmental Chemistry \\ University of Agriculture in Krakow, Poland \\ ${ }^{5}$ Department of Agrochemistry and Plant Nutrition \\ Slovak University of Agriculture in Nitra, Slovakia \\ ${ }^{6}$ Department of Crop Sciences \\ University of Natural Resources and Life Sciences Vienna, Austria
}

\begin{abstract}
Soybean (Glycine max [L.] Merr.) is the major protein and oilseed crop worldwide. Soybean seeds are a rich source of spermidine and other polyamines, which have various positive health effects such as anti-ageing, antioxidant or anti-inflammatory properties. Beside its macronutritional composition, soybean contains various bioactive compounds adding health-protecting functional properties to soy-based foods. The present research is based on the hypothesis that soil application of nitrogen and sulphur might stimulate soybean seed polyamines in addition to agronomic traits. As effects of fertiliser application on spermidine were unknown before, a respective pot experiment was carried out, applying ammonium sulphate or urea at nitrogen levels of 0,1 or $3 \mathrm{~g}$ per $5 \mathrm{~kg}$ soil in two soybean cultivars. The results indicated that cultivars differed significantly in seed yield, thousand seed weight (TSW) and oil content. For both tested

Jacek Antonkiewicz, PhD, DSc., Department of Agricultural and Environmental Chemistry, University of Agriculture in Krakow, Av. Mickiewicz Adam 21, 31-120 Krakow, Poland; phone +48 1266243 45, e-mail: rrantonk@cyf-kr.edu.pl

* The study was funded by the Internal Grant Agency (IGA) of the Faculty of Regional Development and International Studies of Mendel University in Brno No. 2016/017.
\end{abstract}


cultivars, seed yield, TSW and contents of protein and spermidine were lowest in the unfertilised treatment. The spermidine content increased significantly after the application of each dose of ammonium sulphate $\left(280-283 \mathrm{mg} \mathrm{kg}^{-1} \mathrm{DM}\right)$ or the lower dose of urea $\left(267 \mathrm{mg} \mathrm{kg}^{-1} \mathrm{DM}\right)$ as compared to the unfertilised control $\left(228 \mathrm{mg} \mathrm{kg}^{-1} \mathrm{DM}\right)$. The contrast in spermidine levels between non-sulphur (256 mg kg-1 DM) and sulphur $\left(282 \mathrm{mg} \mathrm{kg}^{-1}\right)$ treatments was significant as well, whereas no significant effects were found for the spermine content. The results demonstrate that an application of appropriate doses of nitrogen and sulphur can increase the content of spermidine in soybean seeds apart from affecting other traits.

Keywords: polyamines, human health, soy-food.

\section{INTRODUCTION}

Soybean (Glycine max [L.] Merr.) is the major protein and oilseed crop worldwide; while soybean is predominantly processed for livestock feed and vegetable oil production, an increasing share is utilized in human consumption, which is due to the superior seed composition, made up of $400 \mathrm{~g}$ $\mathrm{kg}^{-1}$ protein and $200 \mathrm{~g} \mathrm{~kg}^{-1}$ oil on average (Vollmann et al. 2015). Beside its macro-nutritional composition, soybean contains various bioactive compounds adding health-protecting functional properties to soy-based foods. Soybean seeds are also known to contain polyamines such as spermidine and spermine (KALAČ 2014).

A recently considered component of soybean seed with a potentially large health effect is polyamine spermidine (SAGARA et al. 2017), which has various important functional and regulatory properties related to the physiology of cell ageing. In cellular models, spermidine application reversed age-induced memory impairment and neuro-degeneration through induction of autophagy (GupTA et al. 2013). In human diabetic patients, spermidine-mediated autophagy has been demonstrated to reduce endothelial dysfunction, which might decrease the risk of cardiovascular disease (FETTERMAn et al. 2016). Apart from autophagy, antioxidant and anti-inflammatory protective effects of spermidine have been shown in neurodegenerative disease models (JAMWAL, KUMAR 2016).

A growing body of evidence for autophagy-mediated positive effects associated with spermidine suggests that soyfoods rich in spermidine might bear significant health effects. As effects of agronomic treatments, such as fertiliser application, on polyamine levels are largely unknown, the objective of this experiment was to investigate the influence of nitrogen and sulphur application on the concentration of spermidine and other traits in two soybean cultivars. While both symbiotic $\mathrm{N}_{2}$ fixation in root nodules and inorganic nitrogen uptake by the roots are important for obtaining high soybean yields, the present research is based on the hypothesis that soil application of nitrogen and sulphur might stimulate soybean seed polyamines in addition to agronomic traits. 


\section{MATERIAL AND METHODS}

\section{Pot experiment}

A pot experiment was established in an outdoor vegetation hall of the Botanical Garden and Arboretum of Mendel University in Brno during 2016. Mitscherlich vegetation pots were filled with $5 \mathrm{~kg}$ of medium heavy fluvial soil $\left(\mathrm{pH} / \mathrm{CaCl}_{2}-7.4, \mathrm{P}, \mathrm{K}\right.$ and $\mathrm{Mg}$ levels $-47,226$ and $322 \mathrm{mg} \mathrm{kg}^{-1}$, respectively). Mineral fertilisers suitable for pre-sowing were applied in five treatments (Table 1) with 4 replications. Early maturity soybean cultivars Vanessa

Table 1

Experimental fertilisation treatments

\begin{tabular}{|c|c|c|}
\hline $\begin{array}{c}\text { Treat. } \\
\text { No. }\end{array}$ & $\begin{array}{c}\text { Dose of nitrogen / sulphur } \\
\left(\mathrm{g} \mathrm{pot}^{-1}\right)\end{array}$ & Fertiliser \\
\hline 1 & $0 / 0$ & - \\
\hline 2 & $1 / 1.17$ & ammonium sulphate \\
\hline 3 & $3 / 3.51$ & ammonium sulphate \\
\hline 4 & $1 / 0$ & urea \\
\hline 5 & $3 / 0$ & urea \\
\hline
\end{tabular}

(Agroscope, Switzerland) and ES Mentor (Euralis Seeds, France) were sown on 5 May 2016 at density of 10 seeds per pot and were thinned to 2 plants per pot after emergence. Pots were watered to a level of $60 \%$ of maximum capillary capacity. Plants were harvested at full maturity on 15 (Vanessa) and 26 (ES Mentor) September 2016.

\section{Protein and oil content}

From the harvest, about $5 \mathrm{~g}$ of finely ground dry seeds were analysed for the oil and protein content by near-infrared reflectance spectroscopy (NIRS) using a Bruker Matrix-I Fourier transform instrument (Bruker, Ettlingen, Germany). All seed oil and protein content data were expressed in $\mathrm{g} \mathrm{kg}^{-1}$ of oven-dried seed.

\section{Spermidine and spermine concentration}

Polyamines were extracted from ground seed threefold with the use of $0.6 \mathrm{~mol} \mathrm{~L}^{-1}$ perchloric acid. The content of spermidine and spermine was determined by high performance liquid chromatography (LabAlliance, State College, USA; Agilent Technologies, Agilent, Paolo Alto, USA) after the preceding derivatization by dansylchloride. Derivatization, chromatographic separation (ZORBAX Eclipse Plus C18, $50 \mathrm{~mm} \times 3.0 \mathrm{~mm}, 1.8 \mu \mathrm{m}$, Agilent Technologies) and detection (spectrophotometrically $\lambda=254 \mathrm{~nm}$ ) were performed according to DADÁKovÁ et al. (2009) and SMĚLÁ et al. (2004). 


\section{Statistical analysis}

Data were analysed by means of the statistical programme STATISTICA, using analysis of variance (ANOVA) models with fixed effects for cultivars, fertiliser doses, fertiliser forms or sulphur vs. non-sulphur fertilisers. The Tukey's test at $a=0.05$ was used for separation of means.

\section{RESULTS AND DISCUSSION}

Depending on characters, ANOVA revealed significant effects of soybean cultivars and fertiliser treatments, whereas interactions between factors generally were not significant. The two cultivars (Table 2) were significantly

Table 2

Cultivar differences in yield and seed quality

\begin{tabular}{|c|c|c|c|c|c|c|}
\hline Cultivar & $\begin{array}{c}\text { Seed yield } \\
\left(\mathrm{g} \mathrm{pot}^{-1}\right)\end{array}$ & $\begin{array}{c}\text { TSW } \\
(\mathrm{g})\end{array}$ & $\begin{array}{c}\text { Oil } \\
\text { content } \\
\left(\mathrm{g} \mathrm{kg}^{-1}\right)\end{array}$ & $\begin{array}{c}\text { Protein } \\
\text { content } \\
\left(\mathrm{g} \mathrm{kg}^{-1}\right)\end{array}$ & $\begin{array}{c}\text { Spermidine } \\
\text { content } \\
\left(\mathrm{mg} \mathrm{kg}^{-1}\right)\end{array}$ & $\begin{array}{c}\text { Spermine } \\
\text { content } \\
\left(\mathrm{mg} \mathrm{kg}^{-1}\right)\end{array}$ \\
\hline ES Mentor & $13.6 a$ & $194 a$ & $176 b$ & $395 a$ & $262 a$ & $29.3 a$ \\
\hline Vanessa & $12.3 b$ & $168 b$ & $189 a$ & $385 a$ & $259 a$ & $29.2 a$ \\
\hline LSD5 & 1.03 & 11.9 & 9.3 & 15.8 & 18.9 & 1.74 \\
\hline
\end{tabular}

TSW - thousand seed weight. Different letters $(a, b)$ indicate significant differences at the level of $a=0.05$ between cultivars.

different in seed yield, thousand seed weight (TSW) and oil content, but did not differ in the protein and polyamine content.

Biological $\mathrm{N}_{2}$ fixation and mineral soil or fertiliser $\mathrm{N}$ are the main sources of meeting the $\mathrm{N}$ requirement of high-yielding soybeans (STREETER, WonG 1988). Soybean requires a starting dose of nitrogen at the beginning of plant growth. Starter-N application is directed at providing readily available soil-N during the seedling development and has been shown to increase soybean grain yields (Touchton, Rickerl 1986). As shown in Table 3, seed yield, TSW, protein and spermidine content were the lowest in the unfertilised treatment. Both fertilisers significantly increased seed yield at the low $\mathrm{N}$ doses as compared to the high ones. There were no differences in seed yield between ammonium sulphate and urea. In contrast, BRAHIM et al. (2017) reported that the application of magnesium sulphate and/or triple superphosphate significantly increased soybean grain yield, suggesting an effect of sulphate. In our experiment, the higher dose of $\mathrm{N}\left(3 \mathrm{~g} \mathrm{~N}^{\mathrm{N}} \mathrm{pot}^{-1}\right)$ was a luxury dose, which depressed the yields (treatments 3 and 5) - Table 3. Nitrate, a major form of inorganic nitrogen in soil, strongly inhibits nodulation and $\mathrm{N}_{2}$ fixation activity (Gibson, Harper 1985, Streeter, Wong 1988). Nitrate inhibition has been shown to have various effects, including a decrease in the nodule num- 
Table 3

Treatment effects in yield and quality traits across both cultivars

\begin{tabular}{|c|c|c|c|c|c|c|}
\hline $\begin{array}{c}\text { Treat. } \\
\text { No }\end{array}$ & $\begin{array}{c}\text { Seed yield } \\
(\mathrm{g} \text { pot })\end{array}$ & $\begin{array}{c}\text { TSW } \\
(\mathrm{g})\end{array}$ & $\begin{array}{c}\text { Oil } \\
\text { content } \\
\left(\mathrm{g} \mathrm{kg}^{-1}\right)\end{array}$ & $\begin{array}{c}\text { Protein } \\
\text { content } \\
\left(\mathrm{g} \mathrm{kg}^{-1}\right)\end{array}$ & $\begin{array}{c}\text { Spermidine } \\
\text { content } \\
\left(\mathrm{mg} \mathrm{kg}^{-1}\right)\end{array}$ & $\begin{array}{c}\text { Spermine } \\
\text { content } \\
\left(\mathrm{mg} \mathrm{kg}^{-1}\right)\end{array}$ \\
\hline 1 & $10.8 a$ & $169.8 a$ & $210 c$ & $327 a$ & $228 a$ & $29.4 a$ \\
\hline 2 & $15.6 b$ & $181.6 a b$ & $192 b$ & $374 b$ & $280 c$ & $30.5 a$ \\
\hline 3 & $10.8 a$ & $186.6 a b$ & $168 a$ & $424 c$ & $283 c$ & $29.2 a$ \\
\hline 4 & $16.5 b$ & $196.0 b$ & $176 a$ & $405 c$ & $267 b c$ & $28.9 a$ \\
\hline 5 & $11.0 a$ & $170.6 a$ & $165 a$ & $418 c$ & $246 a b$ & $28.5 a$ \\
\hline LSD5 & 1.63 & 18.74 & 14.8 & 24.9 & 30.0 & 2.75 \\
\hline
\end{tabular}

Treatments: 1 - control, 2 - ammonium sulphate low, 3 - ammonium sulphate high, 4 - urea low, 5 - urea - high. TSW - thousand seed weight. Different letters $(a, b, c)$ indicate significant differences at the level of $a=0.05$ among treatments.

ber, nodule mass, and $\mathrm{N}_{2}$ fixation activity, as well as the acceleration of nodule senescence or disintegration; therefore, nitrate inhibition cannot be explained simply (Mizukoshi et al. 1995). It has been estimated that only 40 to $52 \%$ of total nitrogen uptake by soybean is from symbiotic di-nitrogen fixation, while the remainder is from soil nitrate uptake (SCHWEIGER et al. 2012). The comparatively low di-nitrogen fixation rate which has implications on seed quality and on the crop rotation value of soybean as compared to other legumes is well in agreement with a meta-analysis on soybean nitrogen fixation, which revealed a negative nitrogen balance in $80 \%$ of cases across a high number of individual studies (SALVAGiotTi et al. 2008). The same authors describe that if the overall $\mathrm{N}$ supply does not meet soybean requirements, the crop will remobilize $\mathrm{N}$ accumulated in leaves to the grain, which diminishes the photosynthetic capacity of the canopy and thus limits the yield potential. In our experiment, the unfertilised treatment (treatment 1) showed visual symptoms of $\mathrm{N}$ deficiency in both varieties. The pot contained only $5 \mathrm{~kg}$ of soil from which mineral nitrogen released from mineralisation was taken up during growth and the di-nitrogen fixation rate did not meet the N-requirements of soybean. Overall, the contradictory results obtained in $\mathrm{N}$ fertilisation studies do not provide clear evidence as to whether $\mathrm{N}$ fertilisation is required to complement the $\mathrm{N}$ supply from biological $\mathrm{N}_{2}$ fixation to achieve soybean yields that approach yield potential levels in a cost effective manner (SALVAGiotTI et al. 2008).

Although the focus of our research was particularly on the content of polyamines, we also monitored other parameters, such as TSW, oil and protein content (Table 3). TSW increased significantly only in treatment 4 as compared to treatments 1 and 5 . As expected, the seed oil content decreased in all the $\mathrm{N}$-fertilised treatments as compared to the unfertilised treatment, 
whereas for the protein content this was exactly the opposite (Table 3). It has been suggested by RATHKE et al. (2005) that this may be a consequence of a reduced availability of carbohydrates for oil synthesis with higher $\mathrm{N}$ supplies causing oil and protein content to vary with $\mathrm{N}$ doses in opposite directions. The inverse relationship between the oil content and the protein content can be explained by their competition for carbon skeletons during carbohydrate metabolism. Since carbohydrate levels are lower in proteins than in oils, an increase in the $\mathrm{N}$ supply results in intensified protein synthesis at the expense of fatty acid synthesis (RATHKE et al. 2005).

Soybean plants require a large amount of $\mathrm{N}$ because the seeds contain a high concentration of protein of approximately $420 \mathrm{~g} \mathrm{~kg}^{-1}$ to $450 \mathrm{~g} \mathrm{~kg}^{-1}$ (VolLMANN et al. 2015) in comparison with pea, blue lupine and bean $207 \mathrm{~g} \mathrm{~kg}^{-1}$ to $321 \mathrm{~g} \mathrm{~kg}^{-1}$ (FoRDOŃSKI et. al 2015). A low protein content might be due to unfavourable environmental conditions and reduced rates of biological di-nitrogen fixation and it was the case in the unfertilised treatment (treatment 1). In our experiment the protein content (Table 3) was significantly higher in all the fertilised treatments than in the unfertilised control.

Recent results demonstrate that concentrations of spermidine and other polyamines are heritable characters in soybean, but there is an environmental influence too (SAGARA et al. 2017). The content of spermidine ( $\left.\mathrm{mg} \mathrm{kg}^{-1} \mathrm{DM}\right)$ increased significantly after the application of both doses of ammonium sulphate (Table 3, treatments 2, 3): $280-283 \mathrm{mg} \mathrm{kg}^{-1} \mathrm{DM}$ (with no mutual differences) and the low dose of urea (267 mg kg-1 DM, treatment 4) as against the unfertilised control (228 $\left.\mathrm{mg} \mathrm{kg}^{-1} \mathrm{DM}\right)$. Comparing sulphur and non-sulphur treatments, the sulphur effect was significant only for spermidine content $(a=0.05)$, and spermidine mean concentrations were 256 and $282 \mathrm{mg} \mathrm{kg}^{-1}$ for non-sulphur vs. sulphur treatments, respectively.

The biosynthesis of polyamines is based on the amino acids arginine and methionine; methionine is a donor of the aminopropyl unit for spermidine and spermine formation (KALAČ 2014). The polyamine pathways from arginine and methionine are regulated by two key enzymes, ornithine decarboxylase and S-adenosyl-L-methionine decarboxylase, respectively (KaLAČ 2014). Sulphur fertilisation of soybean significantly increased methionine and protein content in the grain (KUMAR et al. 1981). Limitation of $\mathrm{S}$ can reduce legume $\mathrm{N}_{2}$ fixation by affecting nodule development and function (SCHERER et al. 2008). Dry soybean is a rich source of spermidine, ranging from 88 to $389 \mathrm{mg} \mathrm{kg}^{-1}$ according to different investigations (GLORIA et al. 2005, KALAČ et al. 2005, Nishibori et al. 2007). Thus, the spermidine level of soybean is considerably higher than in cereals, vegetables, root crops, fruits or most animal food products (Kalač 2014, Nishibori et al. 2007). The effects of fertilisers on the spermidine content have never been explored before. In field experiments, only a significant effect of the weather, i.e. temperature and precipitation, has been described so far, namely SAGARA et al. (2017) reported a higher content of spermidine in a year when temperatures during the seed filling period were clearly lower and precipitation was twice as high as in other years. 


\section{CONCLUSIONS}

The present results for the first time demonstrate that both nitrogen and sulphur fertilisation increase the spermidine content of soybean, whereas the treatments did not affect the content of spermine. Considering the proposed health effects connected with the intake of spermidine, the results reveal an increase of the health-promoting and nutritional value of soybean through fertiliser application. As the present investigation has been carried out under controlled conditions with variation in fertiliser treatments only, further research across growing seasons and locations is needed to quantify other environmental effects on the expression of spermidine levels.

\section{ACKNOWLEDGEMENT}

We express our thanks to the staff of the Botanical Garden and Arboretum of Mendel University in Brno for their helpfulness in this experiment.

\section{REFERENCES}

Brahim S., Niess A., Pflipsen M., Neuhoff D., Scherer H. 2017. Effect of combined fertilization with rockphosphate and elemental sulphur on yield and nutrient uptake of soybean. Plant Soil Environ., 63(2): 89-95. DOI: 10.17221/22/2017-PSE

Dadáková E., KŘížek P., Pelikánová T. 2009. Determination of biogenic amines in foods using ultra-performance liquid chromatography (UPLC). Food Chem., 116: 365-370. DOI: 10.1016/ j.foodchem.2009.02.018

Fetterman J.L., Holbrook M., Flint N., Feng B., Bretón-Romero R., Linder E.A., Berk B.D., Duess M.-A., Farb M.G., Gokce N., Shirihai O.S., Hamburg N.M., Vita J.A. 2016. Restoration of autophagy in endothelial cells from patients with diabetes mellitus improves nitric oxide signaling. Atherosclerosis, 247: 207-217. http://dx.doi.org/10.1016/j.atherosclerosis. 2016.01.043

Gibson A.H., Harper J.E. 1985. Nitrate effect on nodulation of soybean by Bradyrhizobium japonicum. Crop Sci., 25(3): 497-501. DOI: 10.2135/cropsci1985.0011183X002500030015x

Gloria M.B.A., Tavares-Neto J., Labanca R.A., Carvalho M.S. 2005. Influence of cultivar and germination on bioactive amines in soybeans (Glycine max L. Merril). J. Agric Food Chem., 53(19): 7480-7485. DOI: 10.1021/jf0509310

Gupta V.K., Scheunemann L., Eisenberg T., Mertel S., Bhukel A., Koemans T.S., Kramer J.M., Liu K.S.Y., Schroeder S., Stunnenberg H.G., Sinner F., Magnes C., Pieber T.R., Dipt S., Fiala A., Schenck A., Schwaerzel M., Madeo F., Sigrist S.J. 2013. Restoring polyamines protects from age-induced memory impairment in an autophagy-dependent manner. Nat Neurosci., 16: 1453-1460. DOI: 10.1038/nn.3512

Fordoński G., PszczóŁkowska A., Krzebietke S., Olszewski J., Okorski A. 2015. Yield and mineral composition of seeds of leguminous plants and grain of spring wheat as well as their residual effect on the yield and chemical composition of winter oilseed rape seeds. J. Elem., 20(4): 827-838. DOI: 10.5601/jelem.2015.20.2.877

JAMwal S., Kumar P. 2016. Spermidine ameliorates 3-nitropropionic acid (3-NP)-induced striatal toxicity: possible role of oxidative stress, neuroinflammation, and neurotransmitters. Physiol Behav., 155: 180-187. DOI: 10.1016/j.physbeh.2015.12.015

Kalač P., Krizek M., Pelikanova T., Langova M., Veskrna O. 2005. Contents of polyamines in selected foods. Food Chem., 90: 561-564. DOI: 10.1016/j.foodchem.2004.05.019 
KaLAČ P. 2014. Health effects and occurrence of dietary polyamines: A review for the period 2005 - mid. 2013. Food Chem., 161: 27-39. DOI: 10.1016/j.foodchem.2014.03.102

Kumar V., Singh M., Singh N. 1981. Effect of sulphate, phosphate and molybdate application on quality of soybean grain. Plant Soil, 59(1): 3-8. https://doi.org/10.1007/BF02183586

Mizukoshi K., Nishiwaki T., Ohtake N., Minagawa R., Ikarashi T., Ohyama T. 1995. Nitrate transport pathway into soybean nodules traced by tungstate and ${ }^{15} \mathrm{NO}_{3}^{-}$. Soil Sci. Plant Nutr., 41(1): 75-88. http://dx.doi.org/10.1080/00380768.1995.10419560

Nishibori N., Fujihara S., Akatuki T. 2007. Amounts of polyamines in foods in Japan and intake by Japanese. Food Chem., 100(2): 491-497. DOI: 10.1016/j.foodchem.2005.09.070

Rathke G.W., Christen O., Diepenbrock W. 2005. Effect of nitrogen source and rate on productivity and quality of winter oilseed rape (Brassica napus L.) grown in different crop rotations. Field Crop Res., 94(2-3): 103-113. https://doi.org/10.1016/j.fcr.2004.11.010

Sagara T., Fiechter G., Pachner M., Mayer H.K., Vollmann J. 2017. Soybean spermidine concentration: Genetic and environmental variation of a potential 'anti-aging' constituent. J Food Compos Anal., 56: 11-17. https://doi.org/10.1016/j.jfca.2016.11.008

Salvagiotti F., Cassman K.G., Specht J.E., Walters D.T., Weiss A., Dobermann A. 2008. Nitrogen uptake, fixation and response to fertilizer $N$ in soybeans: A review. Field Crop Res., 108(1): 1-13. https://doi.org/10.1016/j.fcr.2008.03.001

Scherer H.W., Pacyna S., Spoth K.R., Schulz M. 2008. Low levels of ferredoxin, ATP and leghemoglobin contribute to limited N2 fixation of peas (Pisum sativum L.) and alfalfa (Medicago sativa L.) under $S$ deficiency condition. Biol Fertil Soils, 44: 909-916. DOI: 10.1007/s00374-008-0273-7

Schweiger P., Hofer M., Hartl W., Wanek W., Vollmann J. 2012. $N_{2}$ fixation by organically grown soybean in Central Europe: Method of quantification and agronomic effects. Europ. J Agron. 41: 11-17. https://doi.org/10.1016/j.eja.2012.01.011

Smělá D., Pechová P., Komprda T., Klejdus B., Kubáň V. 2004. Chromatographic determination of biogenic amines in dry salami during the fermentation and storage. Chem. Listy, 98(7): 432-437. http://www.chemicke-listy.cz/docs/full/2004_07_07.pdf

StreEter J., Wong P.P. 1988. Inhibition of legume nodule formation and $N_{2}$ fixation by nitrate. Crit Rev Plant Sci., 7(1): 1-23. http://dx.doi.org/10.1080/07352688809382257

Touchton J.T., Rickerl D.H. 1986. Soybean growth and yield response to starter fertilizers. Soil Sci Soc Am J., 50(1): 234-237. DOI: 10.2136/sssaj1986.03615995005000010045x

Vollmann J., Watanabe D., Pachner M., Khudaykulov J., Lošák T. 2015. Soybean quality: Adaptation to European needs. Legum. Perspect., 8: 19-20. http://ils.nsseme.com/assets/LegumPerspect8.pdf\#page $=19$ 